\title{
ENGLACIAL AND SUBGLAGIAL HYDROLOGY, AUSTRE OKSTINDBREEN, NORWAY
}

\author{
By W. H. Theakstone
}

(Department of Geography, University of Manchester, Manchester Mi 3 9PL, England)

and N. TVis KNUDSEN

(Laboratoriet for Fysisk Geografi, Geologisk Institut, Århus Universitet, Universitetsparken, 8000 Ârhus C, Denmark)

Abstract. The efficiency of drainage systems within the glacier Austre Okstindbreen apparently increases as the summer progresses. As the transient equilibrium line moves up-glacier and the main system extends headwards, several systems may join together. Much of the detail of the glacier river hydrograph depends on the development of the internal drainage systems, although its general form reflects climatic conditions. Streams flowing from both Austre Okstindbreen and the adjacent, much smaller, steeper glacier, Charles Rabots Bre respond quickly to rain, but the sustained high summer discharge of the Austre Okstindbreen river, even during periods without rainfall and ablation, indicates that much water is stored within the glacier. The volume of water leaving Austre Okstindbreen in summer partly reflects the amount of snow accumulated during the preceding winter. Surface structures and internal drainage systems convey water rapidly towards the margins of both glaciers, but their rivers do not display regular diurnal variations of level until part way into August; at glacier rivers further south, such fluctuations occur throughout the summer. Each year, in late July or early August, a lake dammed by Austre Okstindbreen drains through the glacier. Drainage may be triggered by a decline of water pressure in conduits near the lake.

\section{DISCUSSION}

H. Röthlisberger: Do you have any indication that the temperature might be different in the two events of lake drainage you mentioned?

W. H. Theakstone: Actually, we made no direct observations on temperature but the presence of large ice and snow floes, as well as the inflow of glacial melt water, in both years, indicate a lake temperature close to freezing. 